\title{
Minimal change disease associated with type 1 and type 2 diabetes mellitus
}

\author{
Glomerulopatia de lesões mínimas associada \\ ao diabetes melito do tipo 1 e do tipo 2
}

Miguel Moyses Neto',2, Gyl Eanes Barros Silva ${ }^{3}$, Roberto S. Costa ${ }^{3}$,

Elen A. Romão', Osvaldo Merege Vieira Neto',2, Marcio Dantas'

\section{SUMMARY}

A 19-year-old female with type 1 diabetes for four years, and a 73-year-old female with type 2 diabetes for twenty years developed sudden-onset nephrotic syndrome. Examination by light microscopy, immunofluorescence, and electron microscopy (in one case) identified minimal change disease (MCD) in both cases. There was a potential causative drug (meloxicam) for the 73-year-old patient. Both patients were treated with prednisone and responded with complete remission. The patient with type 1 diabetes showed complete remission without relapse, and the patient with type 2 diabetes had two relapses; complete remission was sustained after associated treatment with cyclophosphamide and prednisone. Both patients had two years of follow-up evaluation after remission. We discuss the outcomes of both patients and emphasize the role of kidney biopsy in diabetic patients with an atypical proteinuric clinical course, because patients with MCD clearly respond to corticotherapy alone or in conjunction with other immunosuppressive agents. Arq Bras Endocrinol Metab. 2012;56(5):331-5

\section{SUMÁRIO}

Uma paciente de 19 anos de idade com diabetes tipo 1 durante quatro anos e uma paciente de 73 anos de idade com diabetes tipo 2 durante vinte anos desenvolveram quadro súbito de síndrome nefrótica. $\mathrm{O}$ exame histológico à microscopia de luz, imunofluorescência e microscopia eletrônica (em um caso) diagnosticou glomerulopatia de lesões mínimas (GLM) em ambos os casos. Na paciente de 73 anos de idade, houve uma associação com o uso de meloxicam. As duas pacientes foram tratadas com corticosteroides e responderam com remissão completa do quadro. A paciente de 19 anos com diabetes tipo 1 apresentou remissão completa sem recidivas, e a paciente de 73 anos com diabetes tipo 2 apresentou dois episódios de recidiva; a remissão completa foi conseguida após associação ao tratamento com ciclofosfamida. As duas pacientes foram seguidas dois anos após a remissão completa. Os casos descritos enfatizam o papel da biópsia renal em pacientes diabéticos com evolução atípica do aparecimento de proteinúria, pois pacientes com GLM respondem bem à corticoterapia como único tratamento ou associado a outro agente imunossupressor. Arq Bras Endocrinol Metab. 2012;56(5):331-5

\author{
${ }^{1}$ Division of Nephrology, \\ Department of Internal \\ Medicine, School of Medicine \\ of Ribeirão Preto, Universidade \\ de São Paulo (FMRP-USP), \\ Ribeirão Preto, SP, Brazil \\ ${ }^{2}$ Serviço de Nefrologia de \\ Ribeirão Preto (SENERP), \\ Ribeirão Preto, SP, Brazil \\ ${ }^{3}$ Department of Pathology, FMRP- \\ USP, Ribeirão Preto, SP, Brazil
}

Correspondence to: mimoyses@gmail.com

Received on 24/10/2011 Accepted on 10/6/2012

\section{INTRODUCTION}

$\mathrm{P}$ roteinuria and nephrotic syndrome, which occur in patients with type 1 diabetes mellitus, are generally due to diabetic nephropathy. However, nephrotic proteinuria is often apparent in patients with insulin-dependent diabetes mellitus (type 1 diabetes), 15-20 years after the onset of diabetes. The natural history of diabetic nephropathy is best described for type 1 diabetes, where the disease onset is more clearly defined.

The natural history of diabetic nephropathy for type 2 diabetes is not clearly defined, and a wide spectrum of non-diabetic glomerular diseases have been described in diabetic patients $(1)$. 
The great majority of patients who are identified as having "minimal change disease (MCD) or lesion" accompanying nephrotic syndrome have a primary or "idiopathic" disorder. However, it is apparent that a similar lesion can appear consequent to a growing number of underlying diseases. The lesion is then known as "secondary MCD". Predisposing conditions include neoplastic diseases, toxic or allergic reactions to drugs, infections and autoimmune diseases (2).

We hereby report two cases of nephrotic syndrome and renal biopsy-proven MCD associated with type 1 and type 2 diabetes who went into complete remission after steroid therapy.

\section{CASE REPORTS}

\section{Case 1}

A 19-year-old female with type 1 diabetes for four years was referred to the department because of facial and bilateral limb edema that was one month in duration. She was being treated with insulin and Aspirin $100 \mathrm{mg} /$ day. She had no arthralgia, skin rash, impetigo, a sore throat or allergies. She had an uneventful pregnancy with a stillborn child eight months earlier. Physical examination revealed a well-developed female with a blood pressure of $90 / 70 \mathrm{mmHg}$, pulse 80 beats/min, normal breathing and no fever. The patient's eyeground was examined; no abnormalities were found. Her weight at that time was $60.7 \mathrm{~kg}$, and her baseline weight was approximately $51.0 \mathrm{~kg}$. She had pitting edema on the legs and face. Her heart and lungs were normal, and no liver, spleen or lymph node enlargement were detected.

Urinalysis showed 10 white blood cells and no red blood cells per high-power field and granular casts. Proteinuria was $5.3 \mathrm{~g} / 24 \mathrm{~h}$; blood urea, $33.0 \mathrm{mg} / \mathrm{dL}$; serum creatinine, $0.7 \mathrm{mg} / \mathrm{dL}$; serum total protein, $4.2 \mathrm{~g} /$ $\mathrm{dL}$; albumin, $1.6 \mathrm{~g} / \mathrm{dL}$; total cholesterol, $463 \mathrm{mg} / \mathrm{dL}$; blood glucose, $326 \mathrm{mg} / \mathrm{dL}$; and hemoglobin, $13.8 \mathrm{~g} /$ dL. Serology for hepatitis B and C, HIV, vasculitis and lupus were negative. A percutaneous renal biopsy was performed. The specimen included 44 glomeruli, and 2 of these were sclerosed. The remaining glomeruli did not exhibit any mesangial expansion, nodule formation, microaneurysms, fibrin cap, or capsular drop lesion. The glomerular basal membrane appeared normal in thickness and contour. The remaining glomeruli and the tubulointerstitial compartment were unremarkable by light microscopy (Figure 1). In the vascular compartment, mild-to-moderate arteriolar hyalinosis, and mild intimal

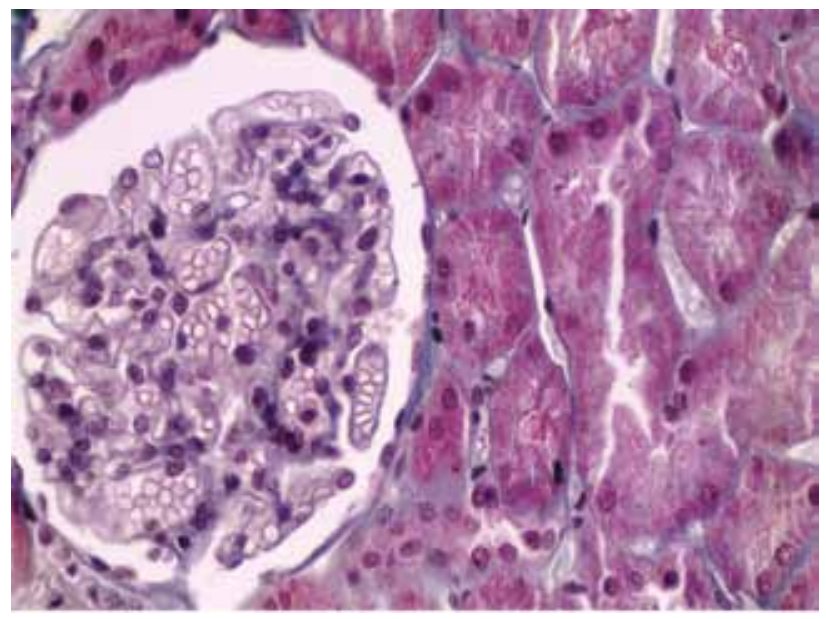

Figure 1. Glomeruli and tubulointerstitial area appear normal under light microscopic examination (Masson's trichromic stain, original magnification: 40x).

thickening were observed. Immunofluorescence was negative for $\operatorname{IgG}, \operatorname{IgM}, \operatorname{IgA}, \mathrm{C} 3, \mathrm{Clq}$, fibrinogen, kappa and lambda light chains. The sample for electronic microscopy contained no glomeruli. Renal histopathologic findings were compatible with MCD.

Prednisone therapy using $60 \mathrm{mg} /$ day was started, and the patient's insulin dosage was increased. The patient went into complete remission with treatment. Prednisone dose was then gradually tapered after 8 weeks of $60 \mathrm{mg} /$ day, and discontinued after 8 months of treatment. At that time, the laboratory findings showed: hemoglobin, $14.7 \mathrm{~g} / \mathrm{dL}$; leukocytes, 11,400/ $\mathrm{mL}$; blood glucose, 90; total cholesterol, $209 \mathrm{mg} / \mathrm{dL}$; serum albumin, $3.9 \mathrm{mg} / \mathrm{dL}$; blood urea, $22.0 \mathrm{mg} / \mathrm{dL}$; serum creatinine, $0.7 \mathrm{mg} / \mathrm{dL}$; urinary sediment without abnormalities; and proteinuria, $47 \mathrm{mg} / 24$ hours. The patient had no relapse during the two years of follow-up.

\section{Case 2}

A 73-year-old female with type 2 diabetes for twenty years, who was being treated with glibenclamide was referred to the department after complaining of an edema that was 20 days in duration. She had back pain for a long time and had been using meloxicam for more than 6 months previously. Physical examination revealed blood pressure of $140 / 90 \mathrm{mmHg}$, pulse of 80 beats/min, normal breathing, and no fever. She had pitting edema of the legs. Her eyeground was examined and no abnormalities were found. Her heart and lungs were normal, and no liver, spleen or lymph node enlargement was detected. Her weight at that time was 60.0 $\mathrm{kg}$, and her baseline weight was approximately 51.0 
kg. Proteinuria was $3.7 \mathrm{~g} / 24 \mathrm{~h}$; serum creatinine, 2.2 $\mathrm{mg} / \mathrm{dL}$; blood urea, $58 \mathrm{mg} / \mathrm{dL}$; serum albumin, 2.2 $\mathrm{g} / \mathrm{dL}$; and $\mathrm{Hb}, 13.0 \mathrm{~g} / \mathrm{L}$. Urinalysis revealed 48,000 red cells $/ \mathrm{mL}$ and 10,000 leukocytes $/ \mathrm{mL}$. Serology for hepatitis B and $\mathrm{C}$, vasculitis and lupus were negative.

A percutaneous renal biopsy was performed. The biopsy specimen contained 21 glomeruli, all of which showed normal mesangial cellularity and matrix, and lacked immune complex deposits. The tubulointerstitial, vascular and glomerular compartments were unremarkable under light microscopy. Immunofluorescence showed diffuse and weak granular mesangial staining for IgM. On electron microscopy, the glomerular capillary membrane was of normal thickness, and podocytes exhibited diffuse effacement of foot processes (Figure 2). This biopsy was compatible with MCD.

Prednisone therapy with $60 \mathrm{mg} /$ day was started. Insulin therapy was introduced, and the patient went into complete remission. Prednisone dose was then gradually tapered after 8 weeks of $60 \mathrm{mg} /$ day, and discontinued after 7 months of treatment. Laboratory data showed the following after this first treatment: $\mathrm{Hb}, 14.3 \mathrm{~g} / \mathrm{dL}$; blood urea, $36 \mathrm{mg} / \mathrm{dL}$; serum creatinine, $0.8 \mathrm{mg} / \mathrm{dL}$; and serum albumin, $3.6 \mathrm{~g} / \mathrm{dL}$. Five months after cessation of prednisone, she experienced a relapse. She was started again on prednisone treatment and went into complete remission. The prednisone dose was tapered until it reached $5 \mathrm{mg}$ ( 5 months later). She had a second relapse of nephropathy. She was started again on steroid treatment, $90 \mathrm{mg}$ daily dose of deflazacort for 8 weeks,

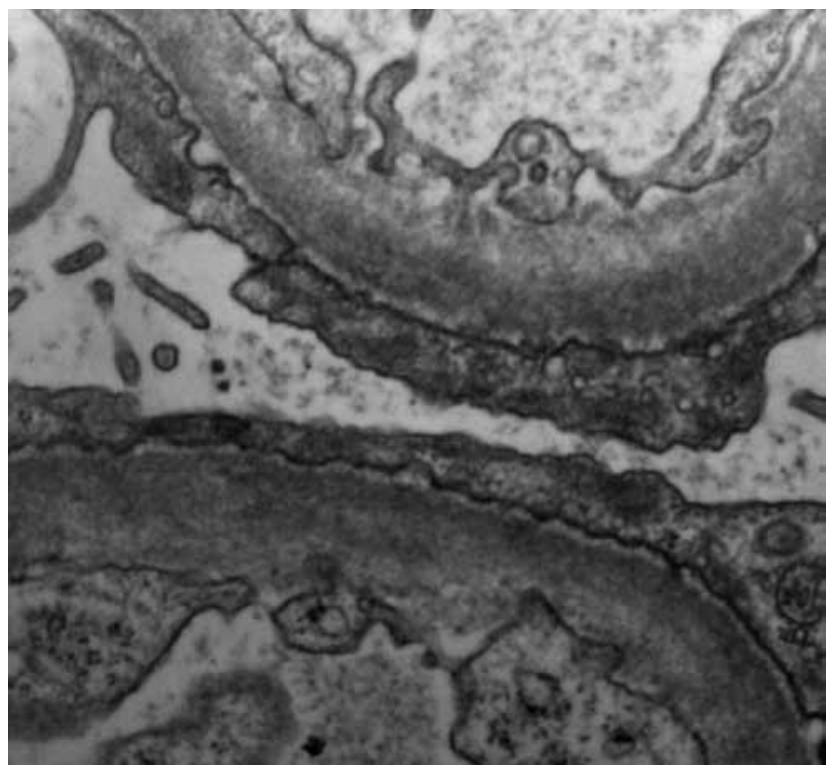

Figure 2. Electron microscopy showing diffuse effacement of the epithelial cell (podocyte) foot processes (original magnification: 10,000x). and during tapering of the dose to $30 \mathrm{mg}, 2 \mathrm{mg} / \mathrm{kg}$ of cyclophosphamide were administered daily to reach an accumulated dose of $200 \mathrm{mg} / \mathrm{kg}(12.0 \mathrm{~g})$. She went into complete remission, which has been sustained for two years after completing treatment.

\section{DISCUSSION}

We report here two cases of a concomitant occurrence of minimal change nephrotic syndrome with type 1 and type 2 diabetes in two female adults. The patient with type 1 diabetes had complete and sustained remission after steroid treatment, while the patient with type 2 diabetes had complete remission after steroid treatment, but had two relapses. Sustained remission was obtained only after steroid treatment concomitant with cyclophosphamide. Both kidney biopsies and clinical outcomes were compatible with MCD. Both cases emphasize the essential role of renal biopsy in diabetic patients who present recent development of nephrotic proteinuria.

Proteinuria rarely occurs within 10 years of the diagnosis of type 1 diabetes mellitus, and the incidence peaks after 15-20 years. In the case described here, the patient had type 1 diabetes for only four years, and had sudden-onset nephrotic syndrome, which made us suspicious of a type of glomerulopathy different from diabetic nephropathy.

There are some reports describing MCD in patients with type 1 diabetes in the literature $(21$ cases in 11 reports), 11 with biopsy-proven $\mathrm{MCD}$, and 10 cases with diagnosis on clinical grounds (3-13). One report showed that the nephrotic syndrome started 6 years before the patient developed type 1 diabetes (13). The authors speculate that this patient may have carried a genetic predisposition for the development of both diseases. In cases of patients with diabetes type 1 and MCD that were described in the literature, the median age was 9 years (range: 3 to 61 years). Most of the patients were younger than 18 years, and only four patients were adults (more than 18 years old) $(3-5,8)$, as was the patient described here. In 7 of the patients, the nephrotic syndrome was presented simultaneously or shortly after the diagnosis of insulin-dependent type 1 diabetes mellitus (median of 24 months, with a simultaneous range of up to 300 months). The patient described here had type 1 diabetes for four years before she developed the nephrotic syndrome. 
The coexistence of MCD and type 1 diabetes does not seem to be a coincidence because these two diseases are known to have immunological pathogeneses and, in some cases, are associated with other immunological diseases (5). The associations between MCD, neoplasms and drugs strongly suggest that some perturbation of cellular immunity is involved (2).

As far as we know, there are only seven previously reported cases of MCD occurring in the setting of type 2 diabetes mellitus (14-20), or in larger reports and reviews (1). Data from these 7 patients are displayed in table 1. In larger reports, many cases were classified as MCD and/or focal segmental sclerosis, but the precise clinical, pathological, and outcome characteristics of these patients were not detailed. The great majority of patients identified as having MCD have a primary or "idiopathic" disorder. Nevertheless, it is apparent that a similar or identical lesion can appear consequent to a growing number of underlying diseases, known as "secondary" MCD (2). There are many conditions that may be associated with MCD, including neoplastic diseases, toxic or allergic reactions to drugs, infections and autoimmune disorders (2). In the case described here, there was an association with the use of an NSAID (meloxicam). In the seven cases described in the literature, only one case of nephrotic syndrome was suspected to have been induced by drugs (acarbose) (19). One patient had diffuse glomerulosclerosis with early nodular changes (18), three had diabetic glomerulosclerosis at a relatively early stage $(17,19,20)$, and other three had no histopathologic changes suggestive of diabetic nephropathy (14-16), as was the case of the patient described here. In addition to nephrotic syndrome, case 2 described here also presented renal failure, which is common in elderly patients with MCD and nephrotic syndrome. Renal failure was resolved following treatment with steroid therapy.

Similar to the majority of the previous cases (3$15,18-20)$, both patients in the present study showed good responses to steroid therapy as the sole treatment in the first episode of MCD. However, in two reports describing MCD and type 2 diabetes $(16,17)$, the patients responded to a single treatment with cyclosporin A in the first episode, which could better control their glycemic levels. In another report (18), the patient experienced spontaneous complete remission, and in another case (14), a 41 year-old man developed sudden onset of nephrotic syndrome, and the percutaneous renal biopsy study showed MCD. Before immunosuppressive therapy, the patient presented Streptococcus sp. bacteremia, and acute renal failure. Afterwards, renal function was recovered, and complete remission of the nephrotic syndrome was observed. In case 2 described here, the patient responded to a combination of steroids and cyclophosphamide, which were administered after the second relapse.

This report emphasizes the need for additional studies of MCD cases associated with type 2 diabetes in order to determine whether there is a common event that induces MCD, and that renal biopsy should be

Table 1. Minimal change disease and type 2 diabetes mellitus

\begin{tabular}{|c|c|c|c|c|c|c|}
\hline Reference & $\begin{array}{c}\text { Duration of } \\
\text { diabetes } \\
\text { (years) }\end{array}$ & $\begin{array}{c}\text { Age } \\
\text { (years) }\end{array}$ & Sex & Etiology & $\begin{array}{l}\text { Histological alterations } \\
\text { (optical microscopy) }\end{array}$ & Treatment \\
\hline $\begin{array}{l}\text { Enriquez } \\
\text { and cols. (14) }\end{array}$ & 10 & 41 & M & Unknown & Normal & $\begin{array}{l}\text { Spontaneous remission after } \\
\text { Streptococcus bacteremia }\end{array}$ \\
\hline $\begin{array}{l}\text { Garcia Donaire and cols. } \\
\text { (15) }\end{array}$ & $?$ & $?$ & $\mathrm{~F}$ & Unknown & Normal & $\begin{array}{l}\text { Prednisone and Prednisone + } \\
\text { chlorambucil after relapse }\end{array}$ \\
\hline $\begin{array}{l}\text { Makibayashi and cols. } \\
\text { (16) }\end{array}$ & 2 & 67 & M & Unknown & $\begin{array}{l}\text { Mild increase in mesangial } \\
\text { matrix }\end{array}$ & Prednisone \\
\hline Matsuda and cols. (17) & 10 & 65 & M & Unknown & Normal & Cyclosporin A \\
\hline Pabico and cols. (18) & 10 & 28 & $\mathrm{~F}$ & Unknown & $\begin{array}{l}\text { Diffuse glomerulosclerosis } \\
\text { and early nodular changes }\end{array}$ & Spontaneous remission \\
\hline Sanada and cols. (19) & 10 & 62 & M & Unknown & $\begin{array}{l}\text { Glomerular hypertrophy and } \\
\text { mesangial expansion }\end{array}$ & Prednisolone \\
\hline Stokes and cols. (20) & 4 & 62 & M & Acarbose & $\begin{array}{l}\text { Mild increase in mesangial } \\
\text { matrix }\end{array}$ & Cyclosporin A \\
\hline Present case & 20 & 73 & $\mathrm{~F}$ & Meloxicam use & Normal & $\begin{array}{l}\text { Prednisone and prednisone + } \\
\text { cyclophosphamide after relapse }\end{array}$ \\
\hline
\end{tabular}


considered in diabetic patients with an atypical clinical course (abrupt onset of nephrotic syndrome and absence of retinopathy as in this case, younger patients and shorter duration of diabetes) because these patients with MCD clearly respond to corticotherapy and/or other immunosuppressive therapies.

Acknowledgements: this study was supported by Fundação de Apoio ao Ensino, Pesquisa e Assistência (FAEPA).

Disclosure: no potential conflict of interest relevant to this article was reported.

\section{REFERENCES}

1. Mazzucco G, Bertani T, Fortunato M, Bernardi M, Leutner M, Boldorini $R$, et al. Different patterns of renal damage in type 2 diabetes mellitus: a multicentric study on 393 biopsies. Am J Kidney Dis. 2002;39:713-20.

2. Glassock RJ. Secondary minimal change disease. Nephrol Dial Transplant. 2003;18 Suppl 6:vi52-8.

3. Aviles-Santa L, Alpern R, Raskin P. Reversible acute renal failure and nephrotic syndrome in a Type 1 diabetic patient. J Diabetes Complications. 2002;16:249-54.

4. Brulles A, Caralps A, Vilardell M. Nephrotic syndrome with minimal glomerular lesions (lipoid nephrosis) in an adult diabetic patient. Arch Pathol Lab Med. 1977;101:270.

5. Dornan TL, Jenkins S, Cotton RE, Tattersall RB, Burden RP.The nephrotic syndrome at presentation of insulin-dependent diabetes mellitus; cause or coincidence? Diabet Med. 1988;5:387-90.

6. Gilboa N, Durante D, Mclntosh RM, Guggenheim S. Etiologic variability of nephropathy in juvenile diabetes mellitus. Arch Pathol Lab Med. 1979;103:479-82.

7. Goldman M, Hebert D, Geary DF. Management of steroid-sensitive nephrotic syndrome in children with type 1 diabetes. Pediatr Nephrol. 2002;17:351-4.
8. Kagiyama S, Tsuruta H,Tominaga M, Morishita K, DoiY, Onoyama K. Minimal-change nephrotic syndrome and acute renal failure in a patient with aged onset insulin-dependent diabetes mellitus and autoimmune thyroiditis. Am J Nephrol. 1999;19:369-72.

9. McCrory WW, Naijar S, Read CH, Vernier RL. Observations on the nature of the nephrotic syndrome occurring in young diabetes. Am J Dis Child. 1960;100:764.

10. Robinson GC, McConnell D. Simultaneous onset of diabetes mellitus and the nephrotic syndrome. Can Med Assoc J. 1961;85:80-1.

11. Urizar RE, Schwartz A, Top F Jr, Vernier RL. The nephrotic syndrome in children with diabetes mellitus of recent onset. $\mathrm{N}$ Engl J Med. 1969;281:173-81.

12. Wass JA, Watkins PJ, Dische FE, Parsons V. Renal failure, glomerular disease and diabetes mellitus. Nephron. 1978;21:289-96.

13. Peces R, Riera JR, Lopez Larrea C, Alvarez J. Steroid-responsive relapsing nephrotic syndrome associated with early diabetic glomerulopathy in a child. Nephron. 1987;46:78-82.

14. Enriquez $R$, Sirvent $A E$, Padilla $S$, Andrada $E$, Amoros F, Fernandez-Lozano JA, et al. Remission of minimal change disease in Type 2 diabetes after streptococcus bacteremia. Clin Nephrol. 2009;71:179-82.

15. Garcia Donaire JAG, Manzanera MJ, Espejo VB, Martinez G, Praga $M$. Sindrome nefrótico recidivante por lesiones mínimas em um paciente diabetico. Nefrologia. 2004;24:179-82.

16. Makibayashi K, Fukatsu A, KitaT. [Complete remission of minimal change nephrotic syndrome with type 2 diabetes mellitus treated by microemulsion formulation of cyclosporin and fluvastatin]. $\mathrm{Ni}$ ppon Jinzo Gakkai Shi. 2002;44:109-13.

17. Matsuda $M$, Hayashi $Y$, Shikata $K$, Makino $H$, Shikata $Y$, Sugimoto $\mathrm{H}$, et al. A case of early-stage diabetic nephropathy complicated by minimal change nephrotic syndrome treated with cyclosporin A. Nephron. 1997;75:490-1.

18. Pabico RC, Panner BJ, McKenna BA, Freeman RB. Spontaneous remission of the nephrotic syndrome in diabetic nephropathy. Am J Med. 1975;59:434-43.

19. Sanada S, Hotta O, Sato M, Taguma Y. Can minimal change nephrotic syndrome superimposed on diabetic nephropathy be diagnosed? Clin Nephrol. 2006;64:81-2.

20. Stokes MB, Kwakye J, D'Agati VD. Nephrotic syndrome and ARF in a diabetic patient. Am J Kidney Dis. 2003;41:1327-33. 